\title{
The Effectiveness of Motivational Interviewing Counseling to Improve Psychological Well-Being on Students with Online Game Addiction Tendency
}

\author{
Mayang T Afriwilda*, (D) Mulawarman Mulawarman \\ Universitas Negeri Semarang, Indonesia \\ ⓜayangtamara8@gmail.com*
}

Article Information:

Received December 10, 2020

Revised January 22, 2021

Accepted February 16, 2021

Keywords: counseling; motivational interviewing; psychological well-being

\begin{abstract}
Psychological well-being is a condition of a person who is not only free from pressure or mental problems but a mental condition that is considered healthy and functioning optimally. This study aims to determine the strength-based counseling intervention based on motivational interviewing to improve psychological well-being. This study uses an experiment with a pretest-posttest control group design. 32 eleventh-grade students in high schools in the city of Semarang involved as participants. Participants were selected using purposive sampling (low psychological well-being and online game tendency), then divided into a control group and an experimental group. The results showed that during the measurement period pre-test, post-test, and follow-up here was a significant difference $(t=-9.670, p>.05)$ in the experimental group, while in the control group ( $t=-7.936, p>.05)$. It can be said that when viewed from the pre-test, post-test, and follow-up intervention the use of motivational interviewing to increase the level of psychological well-being is more significant than the intervention in the control group. As the result, there is a significant change in student's psychological well-being after counseling with motivational interviewing.
\end{abstract}

\section{INTRODUCTION}

The industrial revolution 4.0 is an era that combines automation technology with cyber that brings changes to the order of life (Puncreobutr, 2016; Rojko, 2017). One of them is turning games into a trend for teen recreational activities (King \& Delfabbro, 2019). However, excessive involvement in games can lead to the risk of addiction (Muller et al., 2014). Game addiction is part of internet addiction being recognized as a mental health condition that impacts individual well-being (Psychlopaedia, 2016).

Based on data compiled from Newzoo, AppAnnie, Forbes, TechinAsia in 2017, Indonesia is ranked 16th in the world with 43.7 million gamers and 10-20 years old with a percentage of 36\% (Saputra, 2018). In Indonesia, several studies state that online game addiction causes students to be unable to stop playing, fatigue, skipping school, lack of social interaction, hallucinations, decreased academic performance (Efendi, 2014; Kurniawan, 2017), speaking and behaving rudely, to crimes such as stealing parent's money (Eskasasnanda, 2017).

Previous research has further linked internet activity such playing online games in particular and wider Internet use with a number of negative mental health problems such as poor psychological functioning and stress (Sampasa-Kanyinga \& Lewis, 2015), low self-

How to cite:

E-ISSN:

Published by:
Afriwilda, M., \& Mulawarman, M. (2021). The Effectiveness of Motivational Interviewing Counseling to Improve Psychological Well-Being on Students with Online Game Addiction Tendency. Islamic Guidance and Counseling Journal, 4(1). https://doi.org/10.25217/igcj.v4i1.1235 2614-1566

Institut Agama Islam Ma'arif NU (IAIMNU) Metro Lampung 
esteem (Fioravanti et al., 2012), depression (van den Eijnden et al., 2008), loneliness and even suicidal ideation (Mitchell et al., 2015).

According to Yusuf (2006), to fulfill the task of developing adolescents, they must be able to achieve emotional independence, be able to develop interpersonal communication, learn to get along with peers, have social responsibility, and be able to control themselves. Psychological well-being is a condition of a person who is not only free from stress or mental problems, but a mental condition that is considered healthy and functioning optimally. Psychological well-being is used to describe the fulfillment of positive psychological functioning criteria (Effendy, 2016; Ryff \& Keyes, 1995). Specifically, Ryff \& Keyes (1995) divides psychological well-being into six main dimensions, namely, the extent to which individuals have the quality of positive relationships with others, the individual's ability to accept himself, have a life purpose, be able to grow personally, be able to control the environment effectively and become an independent person (autonomy).

Psychological well-being is very important for students because it has a significant effect on development (Hidayah et al., 2016) and it an indicator of low mental health and being not motivated in the academic process (Okoli \& Okoli, 2018). Because psychological well-being is considered a challenge, effort, personal development and striving to grow (Özen, 2005; Waterman, 1992). Kim (2017) stated that the psychological well-being of adolescents should be understood as a function of individual and contextual characteristics.

The results of the research by Misero \& Hawadi (2012) found that adolescents who have good psychological well-being are able to feel pleasure, are able to avoid stress, are effective in solving problems, and are committed to academic achievement. Another study from Megawati \& Herdiyanto (2016) found that psychological well-being is positively related to prosocial behavior. This means that good psychological well-being will also be accompanied by high prosocial behavior. These findings indicate that good psychological well-being in adolescents appears from optimal functioning in all aspects of psychological development, namely positive feelings and emotions about oneself, being able to solve problems, and also the existence of social connection.

Based on the research conducted by Twenge \& Campbell (2018) who examined the relationship between screen time and lower psychological well-being among children and adolescents. However, this study has several limitations, the survey items combined TV and electronic games into one question, which allowed only an analysis of total screen time and not any differentiation between legacy media (TV) and digital media (electronic games, Internet, social media, etc.), Second, the survey assessed only weekday screen time, and screen time may be higher on weekends. Current research is based on the recommendation that are screening and interventions are needed to help promote low psychological well-being caused by digital media. Therefore, to improve psychological well-being requires interventions that focus on self-motivation to achieve a commitment to change (Griffiths et al., 2012; Xu et al., 2011).

One approach to the strength-based paradigm and focus to build motivation is motivational interviewing. Motivational interviewing counseling emphasizes the development of strengths by identifying one's own strengths (Jones-Smith, 2013). The results of previous research show that strength-based counseling is effective for increasing resilience (Suranata et al., 2017). Likewise, strength-based cognitive therapy is also effective in increasing student resilience (Fadhillah et al., 2017; Padesky \& Mooney, 2012). Oneother studies have also shown motivational interviewing counseling can support self-empowerment, and believe that everyone has the ability to solve problems and achieve goals (Manthey et al., 2011). Although using a strenght based paradigm, previous research has not used a specific specific strategy, besides that research on the efficacy of motivational interviewing is still very limited in the school environment. 
Research Iarussi et al., (2013) explained that counselors need to master motivational interviewing (MI) to develop counseling skills as a professional in the field of counseling. In the implementation of this research was carried out individually, because based on the results of the meta-analysis, the motivational interviewing intervention in the form of an individual has a stronger effect and the results can last in the long term (Jiang et al., 2017; Smedslund et al., 2011). According to the previous explanation and corrects some of the limitations of the above studies, researchers attempted to examine the effectiveness motivational interviewing counseling to improve students' psychological well-being who have tendency to game online addicition.

\section{Rationale of the Current Study}

This study is different from previous studies. in this study specifically to improve the psychological well-being of students by examining the effectiveness of individual counseling with a motivational interviewing approach. The use of motivational interviewing counseling carried out with individual services provides the right means of solving problems that are being experienced by students, because in this counseling is more intensive and more personal (Saputra, 2016). So that in this case students are able to further prove and open their minds in identifying and responding to their problems in order to achieve the expected goals without feeling uncomfortable with the environment that is being felt at the moment (Tutiona et al., 2016).

Based on the research conducted by Twenge \& Campbell (2018) who examined the relationship between screen time and lower psychological well-being among children and adolescents. However, this study has several limitations, the survey items combined TV and electronic games into one question, which allowed only an analysis of total screen time and not any differentiation between legacy media (TV) and digital media (electronic games, Internet, social media, etc.), Second, the survey assessed only weekday screen time, and screen time may be higher on weekends. Current research is based on the recommendation that are screening and interventions are needed to help promote low psychological well-being caused by digital media. Therefore, to improve psychological well-being requires interventions that focus on self-motivation to achieve a commitment to change (Griffiths et al., 2012; Xu et al., 2011).

The research of Manthey et al. (2011) explains that both motivational interviewing and other strength-based practices support personal empowerment and hold the belief that individuals already possess the skills necessary to solve problems and achieve goals. Strength-based practice and motivational interviewing do not expect one to be the expert who is responsible for how an individual change. Conversely, it allows a person to become skilled in facilitating a process of exploring and reinforcing the counselee's goals, values and strengths.

\section{Hypotheses}

1. Individual motivational interviewing counseling is effective in improving psychological well-being students with a tendency to online game addiction

2. There is an interaction effect on the effectiveness of motivational interviewing counseling to improve psychological well-being in students with a tendency to online game addiction

\section{METHODS}

\section{Research Design}

This research is quantitative in nature, and uses an experimental design. The experimental design used was a pre-test and multiple post-test designs involving two groups, 
namely the experimental group and the control group. Counseling activities are carried out face to face.

\section{Participants}

The participants in this study were students of eleventh grade class from several high schools in Semarang, which consisted of 32 students who were divided into two groups (each group consists of 16 students). The participants were selected using purposive sampling technique based on low psychological well-being $(\mathrm{x}<147)$ and high game online addiction $(\mathrm{x}$ $>77$ ). After the subjects were collected, they were collected into two groups, the experimental group and the control group randomly. Participants in the experimental group received treatment in the form of individual counseling with motivational interviewing, while the control group received individual counseling without a spesific approach (treatment as usual).

\section{Instruments}

The instrument used to measure the level of psychological well-being is adapted from the Psychological Well-being (PWB) scale made by Ryff (1989) and Game Online Addiction made by Lemmens et al. (2009). PWB scale consists of six interrelated elements, namely autonomy, environmental control, personal growth, positive relationships with others, goals in life, and self-acceptance. The psychological well-being scale used in this study is a medium form of 42 items with 3 items for each aspect (Ryff, 2014). This instrument has a Cronbach Alpha score of .908.

Then, Game Online Addiction instrument (Lemmens et al., 2009), this instrument is structured based on seven aspects, namely salience, tolerance, mood modification, withdrawal, relapse, conflict, problems. This online game addict behavior scale consists of 21 questions. The reliability of the scale is indicated by Cronbach's alpha .94 . There are no unfavorable items in this instrument.

\section{Procedures}

There are several steps taken. First, the researcher gave a pretest to determine the psychological well-being of students before the intervention. Second, providing 3 sessions of motivational interviewing counseling interventions with $2 \times 45$ minutes allotment for each session. Third, the provision of a post-test to see changes in the psychological well-being of the subject. Fourth, the researchers followed the activity after a two-week post-test.

\section{Data Analysis}

Before testing the hypothesis, the normality test is carried out. The data analysis used was ANOVA repeated measures and paired sample t-test to see changes in pre-test, post-test, and follow-up.

\section{RESULTS AND DISCUSSION}

\section{Results}

Based on the data in Table 1, the participants in this study had an age range between 1417 years with the number of participants based on gender were 21 male students and 11 female students. The division of groups was done randomly.

Based on the data in Table 2, the results of the tests carried out prove that it has a data description with an average level and a standard deviation. The psychological well-being in the experimental group experienced a drastic increase where the mean from pretest $(M=$ 141.75; $\mathrm{SD}=9.18)$ to postest $(\mathrm{M}=182.93 ; \mathrm{SD}=15.57)$ and to follow-up $(\mathrm{M}=202.50 ; \mathrm{SD}=$ $20.07)$, differed. compared pretest $(M=134.75 ; S D=12.94)$ to postest $(M=160.06 ; S D=$ $17.57)$ and to follow-up $(\mathrm{M}=170.31 ; \mathrm{SD}=18.06)$ in the control group. 
Based on the data in Table 3, the present study showed that there is a significant main effect of time on psychological well-being $(\mathrm{F}(2,32=155.760, \mathrm{p}<.01)$. The interaction effect of time and group also significantly affect the level of psychological well-being $(\mathrm{F}(2,16)=$, $\mathrm{p}<.05)$. However, there is no significant effect of time on psychologicall well being in control group.

Based on the data in Table 4, motivational interviewing intervention given to the experimental group in the T1 vs T2 period showed a significant difference $(\mathrm{t}=-9.234, \mathrm{p}>$ $.05)$ while the control group also experienced a significant difference $(t=-5795, \mathrm{p}>.05)$. In other words, the MI intervention had a more significant effect on increasing the level of Psychological Well-being at the T1 vs T2 measurement period than the control group intervention.

Furthermore, during the measurement period T2 VS T3 showed that there was a significant difference $(\mathrm{t}=-6.332, \mathrm{p}>.05)$ to the results of measuring the level of psychological well-being in the experimental group, while the TAU group also experienced an increase $(t=3,617, p>05)$. In other words, the T2 vs T3 intervention MI intervention had a more significant effect on increasing the level of Psychological Well-being at the T1 vs T2 measurement period than the control group intervention.

In addition, during the measurement period T1 vs T3 showed that there was a significant difference $(t=-9.670, p>.05)$ in the experimental group, while in the control

Table 1. Participants demographical information

\begin{tabular}{lcc}
\hline Variables & $\mathrm{N}$ & $\%$ \\
\hline Age (years old) & & \\
14 & 3 & 9.3 \\
15 & 4 & 12.5 \\
16 & 20 & 62.5 \\
17 & 5 & 15.7 \\
Gender & & \\
Male & 21 & 65.6 \\
Female & 11 & 34.4 \\
\hline
\end{tabular}

Table 2. Descriptive data of psychological well-being

\begin{tabular}{lcccccc}
\hline \multirow{2}{*}{ Time of Assesment } & \multicolumn{3}{c}{ Experiment } & \multicolumn{2}{c}{ Control } \\
\cline { 2 - 7 } & $\mathrm{n}$ & Mean & SD & $\mathrm{n}$ & Mean & SD \\
\hline Pre-Test (T1) & 16 & 141.75 & 9.18 & 16 & 134.75 & 12.94 \\
Post-Test (T2) & 16 & 182.93 & 15.57 & 16 & 160.06 & 17.57 \\
Follow up (T3) & 16 & 202.50 & 20.07 & 16 & 170.31 & 18.06 \\
\hline
\end{tabular}

Table 3. Comparison Result Between and Within Group

\begin{tabular}{|c|c|c|c|c|c|c|c|}
\hline \multirow{2}{*}{ Time of Assesment } & \multirow{2}{*}{ Range } & \multicolumn{2}{|c|}{ Experiment } & \multicolumn{2}{|c|}{ Control } & \multirow{2}{*}{$\mathrm{t}$} & \multirow{2}{*}{$F(2,16)$} \\
\hline & & $\mathrm{M}$ & SD & $\mathrm{M}$ & SD & & \\
\hline T1 (Pre-test) & $0-6$ & 141.750 & 9.1833 & 134.750 & 12.948 & 1.764 & \\
\hline T2 (Post-test) & $0-6$ & 182.935 & 15.579 & 160.062 & 17.578 & 3.895 & 22.488 \\
\hline T3 (Follow up) & $0-6$ & 202.500 & 20.073 & 170.312 & 18.061 & 4.768 & \\
\hline $\mathrm{F}(1,16)$ & & \multicolumn{2}{|c|}{130.760} & \multicolumn{2}{|c|}{25.110} & & \\
\hline $\mathrm{F}(2,32)$ & \multicolumn{5}{|c|}{155.760} & & \\
\hline
\end{tabular}

Table 4. Comparison result between the assessment on experiment and control group

\begin{tabular}{lcc}
\hline \multirow{2}{*}{ Comparison } & \multicolumn{1}{c}{$\mathrm{t}$} \\
\cline { 2 - 3 } & Experiment & Control \\
\hline T1 vs. T2 & -9.234 & -5.795 \\
T2 vs. T3 & -6.322 & -3.617 \\
T1 vs. T3 & -9.670 & -7.936 \\
\hline
\end{tabular}

$* \mathrm{~T} 1$ = pre-test, $\mathrm{T} 2=$ post-test, $\mathrm{T} 3=$ follow-up 
group $(t=-7.936, p>.05)$. It can be said that when viewed from the $\mathrm{T} 1 \mathrm{vs} \mathrm{T} 3$ intervention the use of MI to increase the level of Psychological Well-being was more significant than the intervention in the control group.

\section{Discussion}

So that, hypotheses 1 of the results showed that motivational interviewing counseling could effectively improve students' pdychological well-being than the control group. The results of this study reinforce other relevant research which states that motivational interviewing based on expressed principles such as empathy, support for the effectiveness of the counselee's personality, accepting counselee resistance etc. can have interventions with each other (Miller \& Sanchez, 1994; Rollnick \& Miller, 1995). Research studies show that motivational interviewing is directive counseling (with an evidence-based approach) that helps counselees to change their behavior through uncertainty detection and resolution. In other words, the main purpose of motivational interviewing is to treat and handle doubts and ambivalence in the counselee. The counselor also uses such an approach to determine changes in counselee behavior (Imanparvar, 2016).

The results of the research found that motivational interviewing is proven to be effective in improving psychological well-being. Thus, the results found are consistent with other findings which reinforce the fact that motivational interviewing can improve psychological well-being in students with learning difficulties. Psychological well-being refers to a feeling of well-being that includes complete awareness and integrity in all personal aspects. Psychological well-being includes assigning personal cognitive values to life; that is, individuals assign a value to their conditions depending on their expectations and previous experiences (Imanparvar, 2016).

Then, hypotheses 2 of the results describe that there are interaction effects between motivational interviewing group and control group. The results of this study are in line with research (Simmons et al., 2016) which states that this approach requires attention to the existing strengths of a person, family, group, or organization, and utilizes and builds these strengths to help recovery, empower counselees, and build resilience. A focus on strengths offers another avenue to help reduce unwarranted or excessive anxiety, anxiety, and demoralization. Exploring and using strengths can increase immunity to stressors by building habits and protective, pragmatic actions. A focus on strengths will help to transform and reassess challenges, and potentially provide us with a stable dose of well-being to establish positive coping mechanisms (Baker et al., 2017; Rashid \& McGrath, 2020).

Motivational interviewing counseling interventions are able to provide a positive identification effect on low self-esteem and self-control, where before being given the intervention these conditions greatly hamper daily life. However, from the motivational interviewing counseling, students can better understand their internal thoughts, expand their perspective of thinking to be more positive, resolve their ambivalents, try to determine what actions they take, and try to be able to apply them to themselves when they feel difficult situations that are not according to his expectations at that time (Singh, 2019).

\section{Limitations and Suggestion}

The results of this study still have limitations, the study did not measure and analyze the level of tendency of online game addiction in research subjects after being given motivational interviewing (post-treatment) counseling, but only focused on efforts to improve psychologichal well-being. Second, with regard to the research design used, the method of determining the group of research subjects by randomization does not really guarantee that it will create an equal composition of the two groups. Third, in this study, a follow-up plan to determine how changes in the effect after giving the motivational interviewing counseling 
treatment was carried out only with a span of 2 weeks after the last post-test. Future research could analyze the level of well-being of students by gender, or test the efficacy of MI in a group setting and address the limitations of this study.

\section{Implications}

The results of this study provide evidence that the effect of motivational interviewing counseling can have an effective effect on increasing psychologichal well-being in students and can be used as a conceptual and practice reference in the development of future counseling.

\section{CONCLUSIONS}

The findings of this study prove that there is an effect of motivational interviewing counseling approach intervention on students' psychological well-being. Thus, counselors can use motivational interviewing counseling to intervene with students.

\section{AUTHOR CONTRUBUTIONS STATEMENT}

MTA has prepared research designs, collected data at the study site and analyzed the data. MW has provided guidance, instructions, criticisms, and advice in the preparation of research designs and supervision during the research process.

\section{AKNOWLEDGMENTS}

This project is funded by the Ministry of Research and Technology and Higher Education (Ristek-BRIN) funding master's thesis grant program with contract number 056/SP2H/LT/DRPM/2020.

\section{REFERENCES}

Baker, J. C., Williams, J. K., Witvliet, C. V. O., \& Hill, P. C. (2017). Positive reappraisals after an offense: Event-related potentials and emotional effects of benefit-finding and compassion. The Journal of Positive Psychology, 12(4), 373-384. https://doi.org/10.1080/17439760.2016.1209540

D. Griffiths, M., J. Kuss, D., \& L. King, D. (2012). Video Game Addiction: Past, Present and Future. Current Psychiatry Reviews, 8(4), 308-318. https://doi.org/10.2174/157340012803520414

Efendi, N. A. (2014). Faktor Penyebab Bermain Game Online Dan Dampak Negatifnya Bagi Pelajar (Studi Kasus pada Warung Internet di Dusun Mendungan Desa Pabelan Kecamatan Kartasura Kabupaten Sukoharjo) [PhD Thesis, Universitas Muhammadiyah Surakarta]. Google Scholar

Effendy, N. (2016). Konsep flourishing dalam psikologi positif: Subjective well-being atau berbeda. Seminar Asean Psychology \& Humanity, 2004, 326-333. Google Scholar

Eskasasnanda, I. D. P. (2017). Causes and Effects of Online Video Game Playing among Junior-Senior High School Students in Malang East Java. KOMUNITAS: International Journal of Indonesian Society and Culture, 9(2), 191-202. https://doi.org/10.15294/komunitas.v9i2.9565

Fadhillah, A. R., Uyun, Q., \& Sulistyarini, I. (2017). Pengaruh Terapi Kognitif Perilaku Berbasis Kekuatan terhadap Peningkatan Resiliensi pada Remaja Panti Asuhan. JIP (Jurnal Intervensi Psikologi), 9(1), 96-106. https://doi.org/10.20885/intervensipsikologi.vol9.iss1.art7

Fioravanti, G., Dèttore, D., \& Casale, S. (2012). Adolescent Internet Addiction: Testing the Association Between Self-Esteem, the Perception of Internet Attributes, and Preference 
for Online Social Interactions. Cyberpsychology, Behavior, and Social Networking, 15(6), 318-323. https://doi.org/10.1089/cyber.2011.0358

Hidayah, N. H., Pali, M., Muhammad Ramli, \& Hanurawan, F. (2016). Students' Well-Being Assessment at School. Journal of Educational, Health and Community Psychology, 5(1), 62-71. https://doi.org/10.12928/jehcp.v5i1.6257

Iarussi, M. H., Tyler, J. M., Littlebear, S., \& Hinkle, M. S. (2013). Integrating Motivational Interviewing into a Basic Counseling Skills Course to Enhance Counseling SelfEfficacy. Professional Counselor, 3(3), 161-174. Google Scholar

Imanparvar, S. (2016). The Role of Motivational Interviewing in Depression and Psychological Well-Being in Mothers of Students Having Learning Disabilities. AMBIENT SCIENCE, 3(3), 161-174. Google Scholar

Jiang, S., Wu, L., \& Gao, X. (2017). Beyond face-to-face individual counseling: A systematic review on alternative modes of motivational interviewing in substance abuse treatment and prevention. Addictive Behaviors, 73, 216-235. https://doi.org/10.1016/j.addbeh.2017.05.023

Jones-Smith, E. (2013). Strengths-based therapy: Connecting theory, practice and skills. Sage Publications. Google Scholar

Kim, H. H. (2017). The impact of online social networking on adolescent psychological wellbeing (WB): A population-level analysis of Korean school-aged children. International Journal of Adolescence and Youth, 22(3), 364-376. https://doi.org/10.1080/02673843.2016.1197135

King, D. L., \& Delfabbro, P. H. (2019). Video Game Monetization (e.g., 'Loot Boxes'): A Blueprint for Practical Social Responsibility Measures. International Journal of Mental Health and Addiction, 17(1), 166-179. https://doi.org/10.1007/s11469-018-0009-3

Kurniawan, D. E. (2017). Pengaruh Intensitas Bermain Game Online Terhadap Perilaku Prokrastinasi Akademik Pada Mahasiswa Bimbingan Dan Konseling Universitas PGRI Yogyakarta. Jurnal Konseling Gusjigang, 3(1), Article 1. https://doi.org/10.24176/jkg.v3i1.1120

Lemmens, J. S., Valkenburg, P. M., \& Peter, J. (2009). Development and Validation of a Game Addiction Scale for Adolescents. Media Psychology, 12(1), 77-95. https://doi.org/10.1080/15213260802669458

Manthey, T. J., Knowles, B., Asher, D., \& Wahab, S. (2011). Strengths-based Practice and Motivational Interviewing. Advances in Social Work, 12(2), 126-151. https://doi.org/10.18060/959

Megawati, E., \& Herdiyanto, Y. K. (2016). Hubungan antara Perilaku Prososial dengan Psychological Well-Being pada Remaja. Jurnal Psikologi Udayana, 3(1). https://doi.org/10.24843/JPU.2016.v03.i01.p13

Miller, W. R., \& Sanchez, V. C. (1994). Motivating young adults for treatment and lifestyle change. In Alcohol use and misuse by young adults (pp. 55-81). University of Notre Dame Press. Google Scholar

Misero, P. S., \& Hawadi, L. F. (2012). Adjustment Problems dan Psychological Well-Being pada Siswa Akseleran (Studi Korelasional pada SMPN 19 Jakarta dan SMP Labschool Kebayoran Baru). Jurnal Psikologi: PITUTUR, 1(1), 65-76-76. Google Scholar

Mitchell, S. M., Jahn, D. R., Guidry, E. T., \& Cukrowicz, K. C. (2015). The Relationship Between Video Game Play and the Acquired Capability for Suicide: An Examination of Differences by Category of Video Game and Gender. Cyberpsychology, Behavior, and Social Networking, 18(12), 757-762. https://doi.org/10.1089/cyber.2015.0171

Okoli, C. A., \& Okoli, T. (2018). Investigating the Effectiveness of Motivational Interviewing on the Academic Performance of Senior Secondary Students in 
Private School in Niger State, Nigeria. International Journal of Innovative Research \& Development, 7(6). https://doi.org/10.24940/ijird/2018/v7/i6/jun18086.

Özen, Ö. (2005). Ergenlerin öznel iyi oluş düzeyleri. Yayınlanmamış Yüksek Lisans Tezi, Hacettepe Üniversitesi, Ankara. Google Scholar

Padesky, C. A., \& Mooney, K. A. (2012). Strengths-Based Cognitive-Behavioural Therapy: A Four-Step Model to Build Resilience. Clinical Psychology \& Psychotherapy, 19(4), 283-290. https://doi.org/10.1002/cpp.1795

Psychlopaedia, P. (2016, September 16). Internet addiction and online gaming disorder on the rise. Psychlopaedia. https://psychlopaedia.org/?p=6974

Puncreobutr, D. V. (2016). Education 4.0: New Challenge of Learning. St. Theresa Journal of Humanities and Social Sciences, 2(2), Article 2. Google Scholar

Rashid, T., \& McGrath, R. (2020). Strengths-based actions to enhance wellbeing in the time of COVID-19. International Journal of Wellbeing, 10(4), Article 4. https://doi.org/10.5502/ijw.v10i4.1441

Rojko, A. (2017). Industry 4.0 Concept: Background and Overview. International Journal of Interactive Mobile Technologies (IJIM), 11(5), 77-90. Google Scholar

Rollnick, S., \& Miller, W. R. (1995). What is Motivational Interviewing? Behavioural and Cognitive Psychotherapy, 23(4), 325-334. https://doi.org/10.1017/S135246580001643X

Ryff, C. D. (1989). In the eye of the beholder: Views of psychological well-being among middle-aged and older adults. Psychology and Aging, 4(2), 195-210. https://doi.org/10.1037/0882-7974.4.2.195

Ryff, C. D. (2014). Psychological Well-Being Revisited: Advances in the Science and Practice of Eudaimonia. Psychotherapy and Psychosomatics, 83(1), 10-28. https://doi.org/10.1159/000353263

Ryff, C. D., \& Keyes, C. L. M. (1995). The structure of psychological well-being revisited. Journal of Personality and Social Psychology, 69(4), 719-727. https://doi.org/10.1037/0022-3514.69.4.719

Sampasa-Kanyinga, H., \& Lewis, R. F. (2015). Frequent Use of Social Networking Sites Is Associated with Poor Psychological Functioning Among Children and Adolescents. Cyberpsychology, Behavior, and Social Networking, 18(7), 380-385. https://doi.org/10.1089/cyber.2015.0055

Saputra, R. (2018, April 7). Fakta dan Data Game Online. https://www.viva.co.id/indepth/sorot/1024018-fakta-dan-data-game-online

Saputra, W. N. E. (2016). Evaluasi program konseling individu di SMP Laboratorium Universitas Negeri Malang dengan model discrepancy. Jurnal Fokus Konseling, 2(1). Google Scholar

Simmons, C. A., Shapiro, V. B., Accomazzo, S., \& Manthey, T. J. (2016). Strengths-based social work: A meta-theory to guide social work research and practice. Google Scholar

Singh, U. (2019). A study on relative contribution of hardiness, Self-Esteem and learned helplessness in relation to alcohol use. Baba Farid University Nursing Journal, 16(1), 32-36. Google Scholar

Smedslund, G., Berg, R. C., Hammerstrøm, K. T., Steiro, A., Leiknes, K. A., Dahl, H. M., \& Karlsen, K. (2011). Motivational interviewing for substance abuse. Campbell Systematic Reviews, 7(1), 1-126. https://doi.org/10.4073/csr.2011.6

Suranata, K., Atmoko, A., \& Hidayah, N. (2017). Enhancing Students' Resilience: Comparing The Effect of Cognitive-Behavior And Strengths-Based Counseling. 102108. https://doi.org/10.2991/icirad-17.2017.20 
Tutiona, M. Y., Munir, A., \& Ratu, B. (2016). Upaya mengurangi perilaku membolos melalui konseling individual dengan teknik behavior contract pada siswa SMP Negeri 6 Palu. Jurnal Konseling Dan Psikoedukasi. Google Scholar

Twenge, J. M., \& Campbell, W. K. (2018). Associations between screen time and lower psychological well-being among children and adolescents: Evidence from a populationbased study. Preventive Medicine Reports, 12, 271-283. https://doi.org/10.1016/j.pmedr.2018.10.003

van den Eijnden, R. J. J. M., Meerkerk, G.-J., Vermulst, A. A., Spijkerman, R., \& Engels, R. C. M. E. (2008). Online communication, compulsive internet use, and psychosocial well-being among adolescents: A longitudinal study. Developmental Psychology, 44(3), 655-665. https://doi.org/10.1037/0012-1649.44.3.655

Waterman, A. S. (1992). Identity as an aspect of optimal psychological functioning. In Adolescent identity formation ( $\mathrm{pp}$. 50-72). Sage Publications, Inc. https://psycnet.apa.org/record/1992-97345-003

Xu, Q., Wan, Y., Zhang, Y., Liu, Y., \& Sun, Y. (2011). Notice of Retraction: Internet usage and teens' psychological well-being in China. 2011 International Conference on EBusiness and E-Government (ICEE), 1-4. https://doi.org/10.1109/ICEBEG.2011.5881801

Yusuf, S. (2006). Perkembangan Anak dan Remaj. PT. Rineka Cipta. Google Scholar

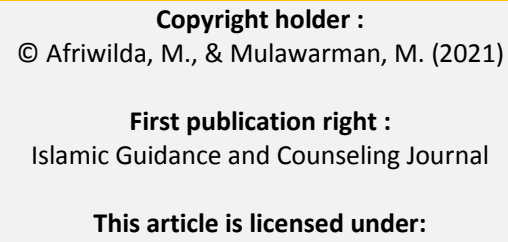

